УДК 784.4:316.323.6(497.7)(049.3)

УДК 791.3:394.1(497)(049.3)

https://doi.org/10.55302/MF2077-78185i

Благица Илиќ

\title{
ОРСКИТЕ И МУЗИЧКИТЕ СОДРЖИНИ - УМЕТНИЧКА ПОТРЕБА НА СВАДБЕНИТЕ ПРОСЛАВИ
}

Апстракт: Предметот на истражување ќе биде насочен кон категоријата кратки традиционални орски и музички изведби, како нова социокултурна и уметничка појава на современите свадбени прослави во Македонија, поточно во градовите Скопје и Гевгелија, како репрезентативни примери за овој вид уметничка појава, која зазема сѐ поголема популарност и практика. За каков вид појава станува збор ќе видиме преку дефинирањето на нејзината форма, преку нејзините елементи и нејзината функција. Од 1991 година, во периодот на осамостојување на Република Македонија, зголемувањето на националното чувство проникна низа различни форми, канализирајќи се и во правецот на политичка, туристичка и економска употребливост. Во овој правец се случи идентитетско ,закрепнување““ и преку нови форми на музичката традиција на свадбените прослави.

Клучни зборови: свадбени прослави, кратки орски изведби, потреба, структура, функција.

Во темата што ќе следи фокусот ќе биде насочен кон категоријата кратки традиционални орски и музички изведби, како нова социокултурна и уметничка појава на современите свадбени прослави во Македонија, поточно во градовите Скопје и Гевгелија, како реперезентативни примери за овој вид уметничка појава, која зазема сѐ поголема популарност и практика. Свадбите се опсежен предмет за истражување. Затоа би започнала со дефинирање на периметарот на мојата тековна студија, која вклучува примери од урбани македонски свадби од 21. век, поточно од последните 20 години и категорија кратки сценски изведби на традиционални орски и музички содржини, како нова социокултурна и уметничка појава - како нејзин фокус, истражен од етнокореолошки и антрополошки аспекти: „Со разбирање на културата во нејзините статички и динамични аспекти ќе бидат разгледани процесите во кои репертоарот на народниот танц - оро - ансамбл „прескокнува над оградата“" од салата за проби и станува значаен културен фактор во социјалните средини““ (Иванова, 2015, 1).

Како предмет на истражување ќе бидат анализирани сегменти од традиционални орски и музички содржини, претставени пред одредена публика, со нивна посебна форма и функција преку изведбите или настапите на неколку фолклорни ансамбли од градот Скопје, вклучувајќи го и професионалниот национален ансамбл за народни игри и песни на Македонија „Танец“, како и: Насоката за традиционална музика и игра при Државниот 
Музичко-Балетски Училишен Центар „Илија Николовски - Луј“, потоа АНПО „Кочо Рацин“; ЖКУД „Владо Тасевски“; Фолклорниот ансамбл „Студио Фолклор“ од Скопје, како и Фолклорниот ансамбл „Бојмија“ од градот Гевгелија. Примерите за анализа беа селективно избрани според квантитетот на појавата, која е предмет на истражување, поконкретно, според честото учество на овие ансамбли на современите свадбени прослави.

За каков вид појава станува збор ќе видиме преку дефинирањето на нејзината форма, нејзините елементи и нејзината функција. Во однос на формата, станува збор за временски кратки сценски изведби во времетраење од 15 до 30 минути, изведувани од најмени игроорци и музичари од фолклорни ансамбли или од културно-уметнички друштва (различно именување, но иста функција на дејствување). Во однос на содржината што ја нудат пред гледачите/публиката, во случајов - гостите на свадбите, пласираат претходно селектирана, подготвена и извежбана програма од најрепрезентативните модели на традиционални орски и музички сегменти, како и динамични игроорни сегменти од кореографии, како дел од стилизираната фолклорна уметност.

Структурата на оваа форма, ќе се потрудиме да ја анализираме преку неколку параметри: содржина на изведба, време на почетоичи и опстојување, учесници (бројност и полова определеност), времетраење на изведба, простор, облековен елемент, музичка придружба, а ке биде следен и соодносот на самата изведба - од една страна и односот на рециичентите/публиката кон неа - од друга страна.

\section{Содржина на изведба - репертоар}

Според анализираните примери, категоријата репертоар на изведба се појавува во различни варијанти на програмско сценарио кај сите фолклорни ансамбли без можност за унифицирана содржинска рамка, но со преклопување на некои заеднички елементи од целокупната изведба. Фокусот ќе биде насочен кон регистрирање на нивниот репертоар како основен елемент на самата појава, без подетална кореолошка и етнолошка критичност. Во најголем број од примерите почетокот на изведбата е потенциран со музички вовед или музичка езгија на зурли и тапани (најчесто две зурли и два тапани), а во некој случај само со изведба на два или повеќе тапани, поради недостаток на зурлаџии (пример со Ансамблот „Бојмија“ од Гевгелија). Постојат и примери на изведба со помош на снимена музика (плејбек) кога отсуствува зурлаџиско-тапанџиски состав, како и употреба на инструментите: хармоника, гитара, кларинет, тарабука, виолина во случај кога програмата е подготвена од сегменти на кореографски постановки. Во случај на употреба на тапанџиско-зурлаџиски состав, музичарите го означуваат почетокот на изведбата и истовремено се предводници на групата изведувачи - игроорци. Според потребата на организаторите на свадбата, изведбата може да биде на почетокот на свадбата или за време на служење на ручекот или на вечерата. Кога се случува на почетокот на самата свадба, во некои примери се изигруваат најрепрезентативните македонски традиционални ора: 
Невестинското оро (модел од кореографијата Невестинско од Ансамбл „Танец“) или Лесното - Правото оро. Во случајот со „Танец“ и АНПО „Кочо Рацин“, почетокот се најавува со изведба на машкото оро Тешкото. Карактеристични се примерите за почеток на свадбена прослава кога кон групата изведувачи се приклучуваат и самите младоженци со кои претходел договор и подготовка во ансамблот. Ансамблот „Кочо Рацин“, практикува заигрување на младоженците заедно со останатите игроорци: со орото Невестинско - за невестата и Тешкото - за младоженецот, со додавање облековни елементи на младоженецот (капа - кече и марама), качување на тапан (во поретки случаи и на невестата) и поклонување пред масата на кумот. Во друга варијанта, по примерот на Ансамблот „Бојмија“, кога изведбата започнува на почетокот на свадбата, се користат два или повеќе тапани со музичка езгија и најава за влез на останатите изведувачи, кои ги заигруваат младоженците со орото Лесното или Правото. Во случај на изведба од учениците на Насоката за традиционална музика и игра, при ДМБУЦ „Илија Николовски-Луј“ од Скопје, почетокот се најавува со зурлаџиско-тапанџиски состав (два тапани и две зурли) и изведба на игроорците со ората Лесното, Малешевка и Копачката. Програмското сценарио во сите примери го следи принципот на градација во музичка и орска смисла, при што изведбата од побавни и рамни ора преминува во динамични и темпераментни орски или кореографски игроорни обрасци, од репертоарот на самиот ансамбл, како што се кореографиите: Малешевка, Пијанец, Посеље, Драчевка, Копачка, Мариовска тресеница, Пиринско пролетно ияеќе, Калајциско, Копачија. Она што е универзално во сите истражени примери е крајот на изведбата, со општопознати народни песни и ора (македонски новосоздадени песни и традиционални ора, како што се: Копачката, Пајдушко оро, Елено моме, Циганчица, Паланечка тројка, Малешевско оро и други) кога се појавува инклузивност од страна на публиката/гостите и изведбата добива поширока структура.

Во поголем број примери изведбата се случува за време на ручекот или на вечерата со истото регистрирано програмско сценарио како и за време на почеток на свадбата, со исклучок на сегментот на заигрување на младоженците. Програмското сценарио кај сите ансамбли е променливо на различни свадби и во некои пригоди зависи од желбата и побарувањето на организаторите на свадбите (самите младоженци, кумот или блиски роднини и пријатели на младоженците). Она што треба да се нагласи, а се појавува како статичен елемент, се одр едени ора како идентитетски маркери за секој ансамбл - изведувач (Тешкото - кај Ансамблот „Танец“ и АНПО „Кочо Рацин“; Лесното и Копачката - во сите ансамбли, како и општоприфатените традиционални ора). Она што може да се забележи е појавувањето на два контексти на изведба, традиционален и стилизиран. Традиционалниот репертоар е почесто или во некои примери целосно застапен за време на изведбата, за разлика од стилизираниот репертоар, кој најчесто се јавува како надополнување на првиот, традиционалниот, и во поретки случаи и целосно застапен. 


\section{Музичка придружба}

Во повеќето анализирани примери доминантни и примарни се тапанџиско-зурлаџиските состави со музичка езгија на почетокот и на крајот на изведбата, во комбинација од две зурли и два тапани или само два и повеќе тапани, во случај на недостиг на зурлаџии музичари. На оваа инструментална придружба се изведуваат ората: Лесното, Невестинското, Тешкото, Копачката, Малешевка и ороводни песни, како во примерот на Насоката за традиционална музика и игра при ДМБУЦ „Илија Николовски-Луј“ од Скопје. Како секундарни музички инструменти се јавуваат и: хармоника, гитара, кларинет, тарабука и виолина, со кои се придружуваат игроорни сегменти од кореографските стилизирани постановки: Драчевка, Калајциско, Мариовска тресеница, Пиринско пролетно цвеке и останатите погоре споменати ора. И во овој случај се јавува класификација на примарни инструменти (тапани и зурли), кои го придружуваат традиционалниот репертоар и секундарните инструменти, во содејство со кореографските форми.

\section{Учесници}

Според половата класификација, во поголемиот број примери постои пропорционална поделеност на машки и женски учесници, со исклучок на Ансамблот „Танец“, каде што најчесто има машки изведувачи (пет игроорци). Како поредок пример е вклучувањето и на женските игроорки, членки на ансамблот, при изведбата на сегменти од кореографијата Мариовска тресеница. Бројот на изведувачи се движи во помали групи, тројца со тројца или шест со шест игроорци („Студио Фолклор“; ЖКУД „, Владо Тасевски“) или во најголем број од 16 учесници.

\section{Времетраење на изведбата}

Од селектираните примери, времетраењето на сценските изведби се поклопува кај сите групи испитаници/учесници, а е во траење од 15 до 30 минути, вклучувајќи ги и музичките импровизации и орските изведби.

\section{Време на почетоци и опстојување}

Ансамбл што има најголем временски дијапазон на изведба на оваа уметничка појава на современите свадбени прослави од испитаните примери е Националниот ансамбл за народни игри и песни на Македонија „Танец“ од Скопје, со почеток во 1998 година - кога учесниците беа најмувани под името „Танец“. Под ова име настапуваа до 2002 година кога го редефинираа со карактеристичниот назив „Тешкаши“, како резултат на главниот идентификациски симбол - изведбата на орото Тешкото. Активно настапуваат со најголем број изведби (по петнаесетина изведби во годината) најмногу во Скопје, но и во останатите градови. Со најкраток период на 
појавување е Насоката за традиционална музика и игра, со почеток во тековната 2019 година и реализирани три свадбени прослави во Скопје. Ансамблот за народни песни и ора „Кочо Рацин“ настапува од 2009 година, со зголемен интензитет од 2013 година до денес. ЖКУД „Владо Тасевски“, активно учествува од 2007 година до 2015 година. Ансамблот „Бојмија“ ја применуваа оваа сценска форма од 2009 година до денес, а „Студио Фолклор“ од 2013 година до денес.

\section{Простор за изведба - сцена}

Како простор за игра се јавува централната позиција во ресторанот, каде што се изведува свадбата, или на место највидливо за сите присутни гости (на крајните страни на салата). Подиумот во рестораните е наменет да функционира како замена за просторот сретсело, односно како замена за просторот во домот на родителите на младоженецот (во традиционален контекст) и како сцена (позиционирана на исто ниво со гледната точка на публиката - гостите). Кога се вклучува најмена група за изведба, овој простор се претвора во сцена, која има и предни и задни, левии десни точки на влез и на излез. Фактот дека подот за играње е на исто ниво со просторот на останатите гости одигрува големо влијание и на изведувачите и на чувството на публиката дека станува збор за заемна веселба.

\section{Облековен елемент - носија}

Како важен елемент за идентификациско препознавање на една култура е облековниот елемент во традиционален контекст, во нашата употреба именуван како народна носија. Во сите примери на појава на сценска свадбена изведба изведувачите задолжително се костимираат во традиционални носии делумно или целосно оригинални, како и со надополнување од реконструирани стилизирани елементи во носијата, кои, во неколку примери, не соодветствуваат со потеклото на орските изведби. Како најчесто употребувани и презентирани носии се машката носија од пределот Мала Река за изведба на орото Тешкото, женската празнична носија од пределот Мала Река за орото Невестинско и Лесното, машка и женска носија од пределот Пијанец и источниот дел на Славиште, за изведба на ора од Источното игроорно подрачје, а се употребува и носијата од пределот Скопска Блатија. Ги споменавме најчесто употребените примери носии, но секако архивата е поголема и од останатите етнички предели во Македонија. Во ниеден анализиран случај не се појавува градска носија, која го карактеризира модниот стил ала Франга и ала Турка, карактеристични за облекувањето во градските средини од крајот на 19 и од почетокот на 20 век.

Во однос на функцијата се поставува уште едно прашање, зошто и дали истата можеме да ја третираме како нова уметничка и социокултурна појава и потреба на денешните свадби и воопшто нејзиното сфаќање и прифаќање во современиот општествен контекст. Свадбите некогаш и денес имаат важно значење за социјалната заедница и заземаат важен простор за одржување на 
„живата“ орска и музичка традиција, најчесто во оригинална и природна изведба, од гостите на свадбените прослави. Воодушевува фактот дека во нашиов случај, свадбата се јавува со својата примарна функција да понуди простор и можност за орско и музичко надигрување и веселење, но и дополнителна функција, така што во самиот простор нуди и подпростор (сцена) за најмена и однапред договорена орска и музичка изведба на професионални или аматерски изведувачи (игроорци и музичари). Гостите стануваат публика, веселбата добива концертен карактер, а изведбата се доживува со зголемени емоции, колективна горделивост и екстаза, ставајќи ги во втор или на помалку важен план содржинското сценарио, носијата или техниката и стилот при орската изведба. Локал-патриотското и емоционалното воодушевување се јавува како надворешна, највидлива функција на овие изведби, а забавно-уметничката - како внатрешна функција.

Можеме да го употребиме размислувањето на авторот Пеичева цитирано во книгата „Современ контекст на традицијата“ од авторот Петровска-Кузмановска, за значењето на фолклорните фестивали и да го приближиме до значењето на кратките свадбени сценски изведби: „... нивната културна мисија од една страна ја одржува, афирмира и валоризира орската и музичката традиција која преку сценско уредување го претвора усвоеното минато во значајни симболи (оро, мелодија, носија, инструменти, изведба) на архаичното локално културно наследство со модерен национален идентитет, а од друга страна произведува придружни сценски програми со економски интерес или контекст, растегнувајќи ја фолклорната музика како атракциски и индустриски производ на месната имагинација“ (Пейчева, 2008, 232). Асман го потенцира влијанието на одредени социокултурни елементи и симболи, кон градењето на идентификацискиот систем на вредности, наведувајќи дека „преку наведените симболи или елементи се конструира своевидна нова 'инфраструктура на идентитетскиот систем'“ (Асман, 2001, 142-143). Според авторот Петровска-Кузмановска треба да го сватиме општествениот контекст, во кои конкретните сценски појави се создаваат, наведувајќи: „Ако го сфатиме општествениот контекст во кој се создаваат и се развиваат свадбени сценски изведби, полесно ќе ја разбереме нивната популарност, атрактивност и распространетост. Промените што настануваат во современата социокултурна ситуација, укажуваат на неизбежна трансформација на низа елементи во фолклорот“" (Петровска-Кузмановска, 2019, 36).

Од 1991 година, од периодот на осамостојување на Република Македонија, зголемувањето на националното чувство проникна низ различни форми, канализирајќи се и во правец на политичка, туристичка и економска употребливост. Во овој контекст се случи идентитетско ,закрепнување“ и преку нови форми на музичката традиција на свадбените прослави. Во последните 20 години постепено се замени најмувањето на дувачките музички состави (блех-оркестри/трубачи) и како нова атрактивност се појави најмувањето на музички тајфи од зурлаџиско-тапанџиски состав.

Постепено, посебно во изминативе 20 години, овие состави се надоградија со нова форма, изведба на орски и музички содржини од најмени игроорци и музичари од фолклорни ансамбли, која се развива од самото 
појавување до денес, следејќи ги потребите на главните ликови на свадбите (невестата, младоженецот, кумот, свекорот итн.), како и конкурентниот однос од сродните фолклорни групи. Станува збор за нова уметничка појава, чие проникнување е иницирано со изградбата или реафирмирањето на македонскиот идентитет, состојба што иницираше проникнување на нови простори низ кои се канализира сценското пласирање на традиционални вредности. Како непосреден набљудувач - гостин на свадба, но и како директен учесник - организатор на изведба, можам да го нагласам изразеното национално, но и емоционално чувство, кое веднаш се согледува со првиот звучен и визуелен контакт на зурлаџиско-тапанџискиот состав и постепено со појавата на останатите учесници со неприкосновениот примат на орото Тешкото. Како што ќе забележи авторот Вилсон Дејв, „... моќта и значењето на 'Тешкото' биле резултат на градењето национална идеологија во социјалистичкиот период од институциите поддржани од Југославија, активиран како национализам во контекст на нација - држава, само по 1991 година“" (Willson, 2014, 246), година кога македонскиот народ ја доби својата независност од Југославија. Соња Здравкова-Џепароска, исто така, ќе забележи дека „независноста на Македонија, што донесе некои проблеми поврзани со идентитетот и независноста на јазикот, културата и историјата, создаде совршени основи за натамошно популаризирање и промовирање на 'Тешкото' како идентитетски симбол“ (Здравкова-Џепароска, 2016, 181).

\section{ЛИТЕРАТУРА}

\section{Кирилични изданија}

АСМАН, ЯН. (2001). Културната памет. София. Планета 3, 142-143. ПЕЙЧЕВА, Л. (2008). Между Селото и Вселената.София, Академично издателство, 232.

ПЕТРОВСКА К, К. (2019). Современ контекст на традицијата. Скопје.

\section{Латинични изданија}

IVANOVA, N. D. (2015). Wedding as a stage: examples from the Bulgarian urban wedding scene. The 43rd ICTM world conference. Kazakh National University of Arts, 1-2.

ZDRAVKOVA, DJ. S. (2016). Chain Dance Teshkoto- Cultural Identity Marker of Macedonia. Porte Akademik: Journal of Music and Dance Studies. Vol. 14/15, 181. WILLSON, D. (2014). Teshkoto and national sentiment in Macedonia: ascribing meaning, experiencing tradition. Third Symposium of the ICTM Study Group on Music and Dance in Southeastern Europe. Skopje, Macedonia, 246. 


\section{Blagica Ilikj \\ DANCE AND MUSIC CONTENT AS AN ARTISTICNEED FOR WEDDING CELEBRATIONS}

Summary

The subject of the research is focused on the category of short traditional dance and music performances, as a new socio-cultural and artistic appearance of the contemporary wedding celebrations in Macedonia, more precisely in the cities of Skopje and Gevgelija as representative examples of this type of artistic appearance which is gaining popularity and practice. We will find out what kind of appearance it is by defining its form, elements and function. Since the period of independence of the Republic of Macedonia since 1991, the increase of the national feeling has penetrated a series of different forms channeling in the direction of political, tourist and economic usability. In this respect, identity "recovery" has also taken place through new forms of musical tradition at the wedding celebrations. It is a new artistic phenomenon whose penetration was initiated by the construction or reaffirmation of the Macedonian identity, a condition that initiated the penetration of new spaces through which the stage placement of traditional values was channeled. Weddings are, at present, important to the social community and occupy an important space for the maintenance of a "lively" dance and music tradition, often in an original and natural performance by the guests at the wedding celebrations. It is fascinating that in our case, the wedding comes with its primary function to offer space and opportunity for dance and musical ascension and exhilaration, but also an additional function so that in the space itself offers sub space (stage) for hired and pre-arranged dance and music performance of professional or amateur performers (dancers and musicians). Guests become audiences, the celebration gets a concert character, and the performance is enhanced by emotions, collective pride and ecstasy, putting the content script, costume or technique and style of the dancing in a second-hand or unimportant. Local-patriotic and emotional astonishment appears as the outer, most visible function of these performances, and the entertainment-art as the inner function. 